\title{
Research as a Tool in the Elimination of Onchocerciasis
}

\author{
Adewale B* and Mafe MA \\ Public Health and Epidemiology Department, Nigerian Institute of Medical Research, Nigeria
}

Submission: December 13, 2017; Published: January 24, 2018

*Corresponding author: Adewale B, Public Health and Epidemiology Department, Nigerian Institute of Medical Research P.M.B 2013 Yaba, Lagos. Nigeria, Email: badewale@hotmail.com

\section{Mini Review}

Onchocerciasis is one of the five diseases referred to as preventive chemotherapy- Neglected Tropical Diseases (PCNTDs). It affects 37 million people in 31 African countries as well as 3 countries in the Latin America and several areas in Yemen. Nigeria has the highest endemicity among countries responsible for $99 \%$ of infection globally. Blindness and severe skin manifestations are two major effects of the disease on affected populations with severe effects on affected communities. The disease is significantly a disease of the poor with economic implications resulting in further impoverishment of affected communities, a challenge to the achievement of SDGs 2 and 3 and national developmental goals. The main strategy for control in endemic countries is by mass ivermectin (Mectizan $®$ ) distribution. Mass distribution of ivermectin in Nigeria began in 1991 following surveys that determined the extent and intensity of onchocerciasis in Kaduna State [1,2]. The large scale distribution that began in Kaduna State was through community based method through a tripartite agreement between Sightsavers, Kaduna State Ministry of Health and National Eye Centre Kaduna to ensure delivery to all endemic communities [3]. Nigeria has been administering ivermectin annually on a mass scale for over two decades and the status of transmission of the disease or impact of annual drug administration on disease transmission needs to be assessed to determine stoppage of annual MDA in line with the global road map and target for the elimination of the disease. Research efforts have resulted in use of molecular biology technique of PCR pool screening of the Simulium vector fly to ascertain status of transmission in transmission zones as well as the use serological method using ov-16 antigen to detect infection among children $<10$ years old by the use of Dried Blood Spots (DBS) and ELISA and also rapid detection of antibody in whole blood through the use of Biplex kit. Currently according to O'Hanlon [3] national control programmes in the former OCP and the WHO African Programme for Onchocerciasis Control (APOC) are shifting their focus from morbidity control to elimination of the infection where feasible through community-directed treatment with ivermectin (CDTI) which is in three phases according to the guidelines for stopping mass drug administration and verifying elimination of human onchocerciasis [4].

I. Phase 1: The intervention or treatment phase which is characterised by regular ivermectin treatment with a minimum requirement of $80 \%$ therapeutic coverage. This phase typically lasts at least 12 - 15 years, corresponding to the reproductive lifespan of the adult worm when exposed to drug pressure.

II. Phase 2: This phase immediately follows the intervention or treatment phase which is referred to as the "post - treatment surveillance". This typically lasts 3-5 years.

III. Phase 3: This starts at the end of the 3-5 years of "post-treatment surveillance" and is known as post-elimination surveillance.

The results of the current efforts are being awaited to determine the effectiveness of ivermectin in the elimination of onchocerciasis in one of the most endemic countries for onchocerciasis. The results of the current efforts are being awaited to determine the effectiveness of ivermectin in the elimination of onchocerciasis in most endemic and populous country in West Africa.

\section{References}

1. Abiose A, Murdoch I, Babalola O, Cousens S, Liman I, et al. (1994) Distribution and aetiology of blindness and visual impairment in meso-endemic onchocercal communities, Kaduna State, Nigeria. Br J Ophthalmol 78: 8-13.

2. O'Hanlon SJ, Slater HC, Cheke RA, Boatin BA, Coffeng LE, et al. (2016) Model-Based Geostatistical Mapping of the Prevalence ofOnchocerca volvulus in West Africa. PLoS Negl Trop Dis 10(1): e0004328.

3. Tekle A, Elhassan E, Isiyaku S, Amazigo U, Bush S, et al. (2012) Impact of long-term treatment of onchocerciasis with ivermectin in Kaduna State, Nigeria: first evidence of the potential for elimination in the operational area of the African Programme for Onchocerciasis Control. Parasit Vectors 5(1): 28.

4. WHO/HTM/NTD/PCT/2016.1 
- Swift Peer Review

- Reprints availability

- E-prints Service

- Manuscript Podcast for convenient understanding

- Global attainment for your research

- Manuscript accessibility in different formats ( Pdf, E-pub, Full Text, Audio)

- Unceasing customer service

Track the below URL for one-step submission

https://juniperpublishers.com/online-submission.php 